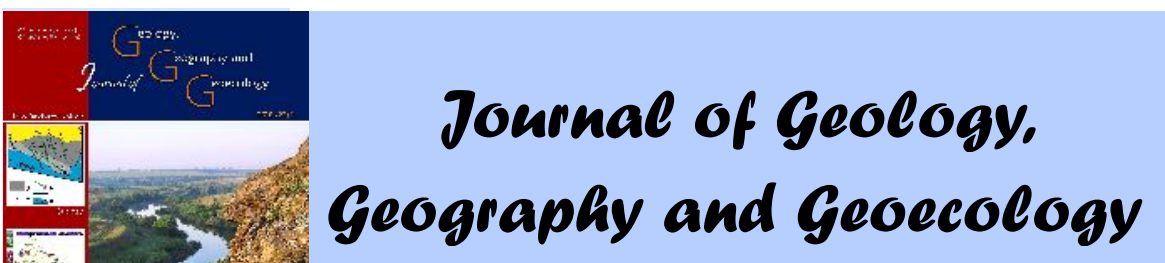

Journal home page: geology-dnu-dp.ua

\title{
Eco-aesthetic features of mineral deposits
}

\author{
P. Baranov ${ }^{1}$, O. Slyvna², O. Matyushkina² \\ ${ }^{1}$ Oles Honchar Dnipro National University, Dnipro, Ukraine, e-mail: pn2dsbaranov@gmail.com \\ ${ }^{2}$ State Higher Educational Institution «National Mining University», Dnipro, Ukraine,e-mail:e.slivna@gmail.com
}

Received 16.04.2018;

Received in revised form 04.05.2018; Accepted 19.06.2018

environment and the entire ecosystem. Extraction from the bowels of the earth of minerals violates the geochemical systems on many decades and centuries, and on occasion changes the landscape of locality. Developed deposits can be economically profitable, ecologically clean and esthetically attractive due to development to the aesthetic and historical aspects. An example is the Wieliczka mine in Poland, where business, ecology and aesthetics are harmoniously combined.

A number of the largest worked out fields and developed fields in Ukraine are in extremely need of the development of this issue. Developed iron ore deposits are one of the important factors of industrial potential of Ukraine. Semiprecious stone material, jaspilite, is the aesthetic aspect of these fields. They have colossal reserves. Using their decorative properties, we have developed the laws of shaping for the design of natural stone, identified the main areas of application of jaspilites in decorative art. Implementation of the idea of creating a Jespilite room will allow Krivbas not only industrial, but also cultural and educational center. The achieved results will qualitatively improve the eco conditions for the local population, the development of stone carving art and will lead to business growth. The explored deposits of spodumene pegmatites in the Western sea of Azov in addition to lithium mineralization contain expansive fields of graphic microcline pegmatites, spodumene and albitic pegmatites. They contain samples of pink spodumene (kunzite), petalite from light green to pink, tourmaline (sherl). Thus, this deposits of spodumene pegmatites in Western Azov today require a comprehensive assessment of minerals, because in addition to ore mineralization there is also a gemstone-colored raw material.

Keywords: environmental aesthetics, geological features, mines, mining, natural processes.

\section{коестетичні особливості родовищ корисних коп лин}

\author{
. $\mathrm{p} \mathrm{нов}^{1}$, . . ливн ${ }^{2}$, . . тюшкин ${ }^{2}$

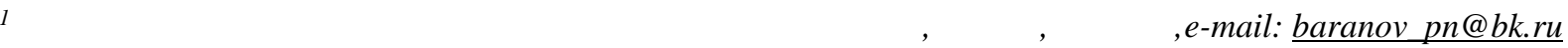 \\ ціон льний гірничий університет, ніпро, кр їн ,e-mail: e.slivna@gmail.com
}

нот ція. ет роботи - вивчення відпр цьов них родовищ, родовищ, які з $\mathrm{p}$ з розробляються, т розвід них родовищ корисних коп лин н предмет екоестетичності, в основу якої покл дено принцип користі (утиліт рність, доцільність) і кр си (естетик ). к критерії оцінки екоестетичності геологічних об'єктів виступ ють економічні, екологічні т естетичні х р ктеристики. ідпр цьов ні родовищ 3 вд ють непопр вної шкоди геологічному середовищу т всій екосистемі. илучення із н др корисних коп лин порушує геохімічні системи н 6 г то десятиліть і століть уперед, в деяких вип дк х змінює л ндш фт місцевості. тільки 3 вдяки впров дженню естетичних т історичних спектів відпр цьов ні родовищ можуть бути економічно прибутковими, екологічно чистими т естетично прив бливими. рикл дом може служити ш хт еличк у ольщі, де г рмонійно поєднуються бізнес, екологія т естетик . изк н йбільших відпр цьов них і розроблюв них родовищ кр їни вкр й потребує вирішення пит ння, що висвітлюється у цій ст тті, для з лізорудних і пегм титових родовищ. стетичним спектом цих родовищ виступ $€$ к менес моцвітн сировин . икористовуючи декор тивні вл стивості природного к меню, розробили з кони формоутворення для його диз йну, визн чили основні н прями використ ння джеспілітів у декор тивно-прикл дному мистецтві. е ліз ція ідеї створення жеспілітової кімн ти дозволить ривб су ст ти не тільки промисловим, й культурно-просвітницьким центром, що якісно поліпшить екоумови для прожив ння місцевого н селення, розвиток к менерізного мистецтв і сприятиме зрост нню бізнесу. озвід ні родовищ сподуменових пегм титів у хідному ри зов ї сьогодні вим г ють комплексного оцінюв ння корисних коп лин, оскільки, крім літієвої мінер ліз ції, тут присутні 
широкі поля гр фічних пегм титів, які н леж ть до н півдорогоцінного к міння. р пляються зр зки рожевого сподумену (кунцит), пет літу від світло-зеленого до рожевого кольору, турм ліну (шерл).

лючові слов : екологічн естетик, геологічне середовище, родовищ корисних коп лин, гірничі виробки, природні процеси.

Introduction. Throughout the course of history of humanity, the geological environment provided economic welfare, served as a stimulus for technical development of the society, created comfortable conditions for rest and living of a human.

The first 20 thousand centuries (the Stone Age) were a period of perfect harmony of a human with the environment. Man took nothing from the geological environment and gave nothing. At the same time the stone was his only protector, assistant, object of admiration and mystification.

With the development of deposits of natural resources the technosphere is emerging, with its industrial enterprises, urban infrastructure, hydrogeological facilities, multi-kilometer quarries and mines. At a certain moment the technosphere reached such scale that began to destroy the creator and the biosphere itself. However, the society tried not to notice it: the obvious threat was not realized, the comfort of living in the usual surrounding ecosystem was not lost. It was believed that the globe is great, the nature is able to adapt, exploitable minerals and other mineral resources are inexhaustible.

Only with the awareness of humanity of its future, it made a stand for the nature. For the first time people started speaking about ecology. The wastefree and low-waste manufacturing facilities, enterprises for processing of household waste, closed cycles of water use have been created.

It is a post-industrial era on the basis of understanding the concept of "nature" and its derivatives and consistent elements that generates a new concept - "ecology", which is altogether understood as a teaching about the functioning of the natural environment.

The complication of living conditions of people is a certain basis for the nascence of environmental aesthetics. The more contradictory and tense human life becomes in modern society, the more often a person turns his eyes to the nature and culture, trying to find the reason for his own existence, harmony and beauty, which are gradually being lost in the growing dynamics of social relations.

Statement of basic materials. Mineral deposits are divided into three main groups according to the degree of development: exhausted, under development, explored.

Exhausted deposits are objects that violate the primary geological environment when extracting non-renewable natural components from it. At the same time, the number of exhausted deposits grows every year, and the number of developed and estimated ones is decreasing. The recultivation of lands on the exhausted deposits is one of the directions of solving environmental problems when arable lands are restored. In countries with weak economies and the lack of environmental organizations, unconscious and consumer attitude to the environment leads to the fact that subsoil users simply throw exhausted objects at the mercy of the nature. But fortunately, this was not always the case and not everywhere. Some geological objects used by man in the operating, cultural and educational activities have become the subject of successful business and environmental safety due to aesthetic appeal.

Deposits that have become cultural and educational centers. A striking example is the exhausted deposit of rock-salt in Poland (Wieliczko mine). The geometrical parameters of ore bodies determined the technology of extraction by mining method. From the 13th to the 20th centuries, industrial salt mining was continuously carried out here, and over time, the technologies and methods of extraction needed for deeper horizons were improved. Now, a mine consists of 7 galleries and goes to a depth of $198 \mathrm{~m}$, and the total length of the development is more than 200 $\mathrm{km}$ (https://www.wieliczka.ru/pro-szachtu/mul-timjedii/fotografii).

Unique achievements in rock-salt mining have always attracted the attention of the public. In the XV century, the Wieliczko salt mine was started to be shown to privileged persons for educational purposes. Until the end of the XVI century, tourism remained elite, and mine workings could be visited only with the permission of the king.

In the XVI century the therapeutic properties of rock salt were identified and proven, what further increased attention to this object. Here they began successfully treating bronchial asthma, bronchial inflammatory conditions, as well as allergic rhinitis.

In order to mine workings acquired aesthetic appearance and special appeal, artistic salt compositions were created: the history of mining development, governmental and historical figures, churchmen, traditions and the culture of the region.

Two environmental problems are known in the history of the mine. The first one occurred immediately after The Great Patriotic War. Inefficient arrangement in rock-salt extracting caused an avalanche, and then the flooding of some mine workings. In the 50s of the XIX century the workings were restored. The second accident occurred in 1992, during the mining workings an aquifer with a 
large flow rate was opened. This was the last catastrophic flooding of the mine, after which it was closed and began functioning only as a tourist attraction.

After the elimination of environmental problems in 1998, UNESCO removed the Wieliczko mine from the list of environmentally hazardous object.

At the present time, the Wieliczko mine is a cultural center, where chamber music competitions, scientific conferences, celebrations (weddings, corporate parties), medical events (Health Day, healthy sleep, three hours of health) (Fig. 1) are held.

Thus, the mining ( the Wieliczko mine) passed on rock-salt has become economically independent, which allows to keep the mine in an environmentally safe state, finding opportunities for the development of art and aesthetics.

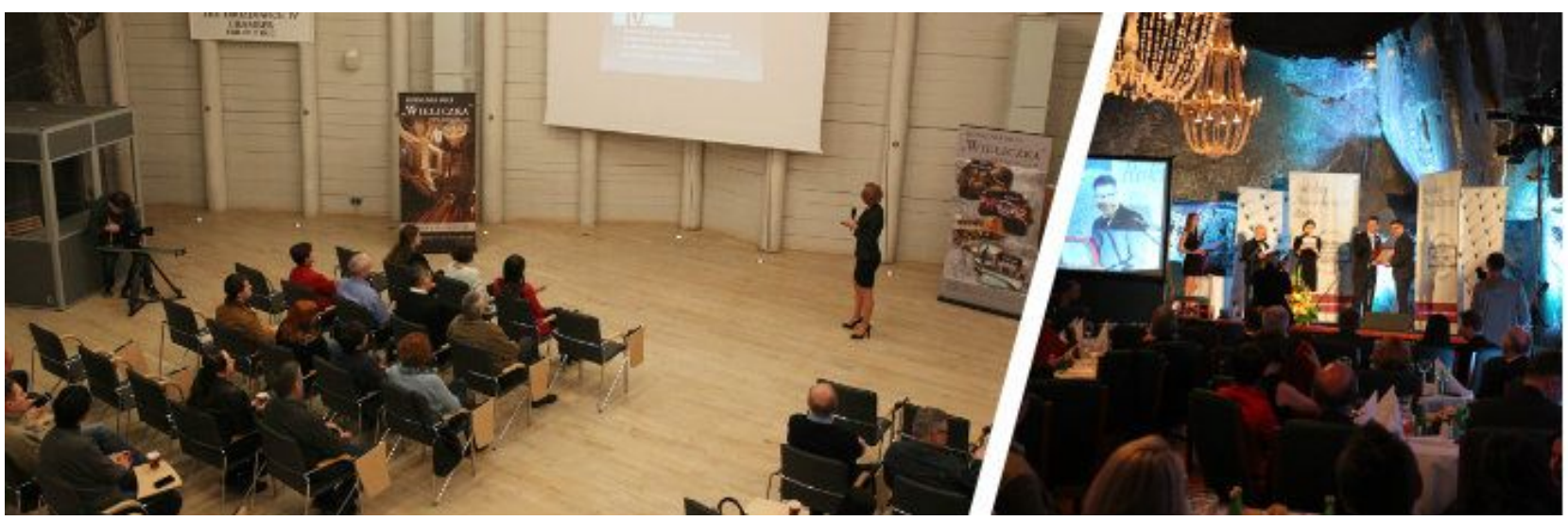

Fig. 1. Cultural events held in the Wieliczko salt mine https://www.wieliczka.ru/pro-szachtu/mul-timjedii/fotografii

At the same time, similar deposits of rock-salt are known on the territory of the Transcarpathian region (Solotvino mines) of Ukraine. Being in the same geological situation (structural, genetic), they created an environmental problem for the area - because of the karst holes many engineering constructions and settlements of the region turned out under the threat of destruction and flooding (Fig. 2).
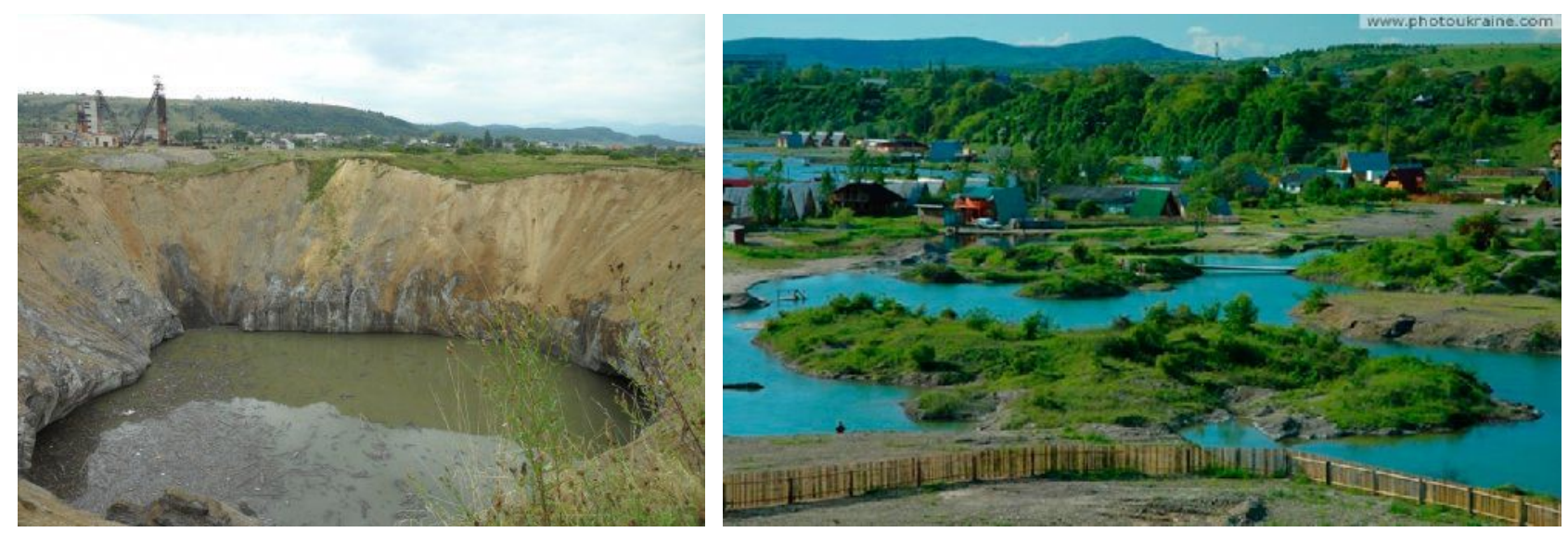

Fig. 2. The karst holes in Solotvyno, the Transcarpathian region https://go.mail.ru/search_images

Deposits having played a big part in art, made a certain contribution to the culture. The Ural deposits of malachite Gumeshevskoye, Mednorudyanskoye and Vysokogorskoye could be taken as an example.

Malachite of the Ural deposits was recognized as unsurpassed in quality material, thanks to the Ural masters, who developed the technique of Russian mosaic (Fersman A. E., 1961). Subsequently, it was shown that the malachite of the Democratic Republic of the Congo (DRC) is not inferior in quality, and the reserves exceed several times (Baranov P. N. et al., 2006).

Nevertheless, masterpieces of world art of the Hermitage created by Ural masters, Moscow Kremlin and Saint Isaac's Cathedral are the top of stone carving skill. Malachite entered the history of decorative and applied arts as a stone, steeped in works of art, folk tales, legends, what allowed it to become a national (Russian) gem.

Malachite has introduced a new direction in arts and crafts, new opportunities in architecture, and world fame to the Urals masters. At the same time, 
the exhausted deposits of malachite (quarries) still remain unclaimed in tourism and in business.

Many well-known deposits of world importance, such as Malyshevskoye (emerald) and Volodarsk-Volynskoye (Topaz, rock crystal) can also be added. There was a time when in the last one the unique precious stones (crystal quartz 10 tons, fiery Topaz $39 \mathrm{~kg}$ ) were mined. After the USSR breakup, these mine workings (mines) were flooded and are beyond repair, according to experts. Although, at the present time, there is certainly a commercial component, and, consequently, environmental problems could be solved simultaneously.

Deposits that have lost gems. Eliseevskoye ore field (Zaporozhye region, Ukraine) was opened at the beginning of the XX century. One of the promising deposits is "Green grave", where, since 1938, ceramic raw materials, represented by graphic pegmatites, and tantalum concentrate were mined. Judging by the fragments that have been preserved in the quarry, pegmatites are represented by albite, microcline varieties and their combinations. However, at that time the country was in desperate need of rareearth - rare-metal raw materials, and this type of raw materials was not relevant because graphic varieties of pegmatites were not considered as stone-colored raw material.

Currently, it is an open pit mining (quarry) of 500x100 m in size, filled with water (fig. 3), which local residents use for agricultural purposes. Uniqueness of this object is that the oldest rocks of Ukrainian shield, lodes of decorative graphic pegmatite (Jewish stone), zoning of ore bodies are observed here; rare minerals of tantalum, zircon, garnet, biotite, muscovite etc. are found. In the Museum of the National University of Kiev a crystal of beryl, up to $30 \mathrm{~cm}$ and $4 \times 5 \mathrm{~cm}$ in diameter from the pegmatites of this Deposit is preserved.

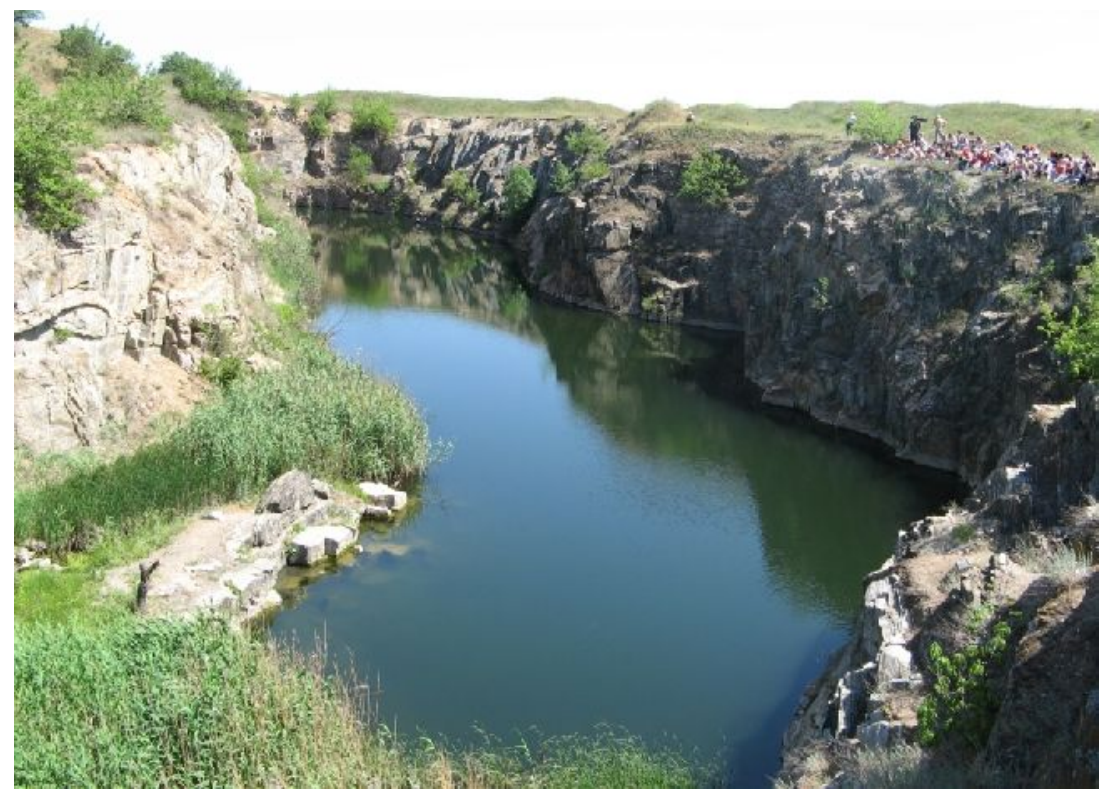

Fig. 3. The waste deposit of written pegmatites "Green Grave".

The next object is an ore field of nickel ores of Sryedneye Pobuzhya, a zone of physical and chemical destruction of ultrabasic rocks. At the stage of the almost completed extraction on deposits of Lipovenkavskoye and Derenyuchinsky, the formations of silica in the shape of sheet deposit, crusts, bundles and solid buildups were discovered (Baranov P. N., M. L. Kutsevol, 1998). They are composed of quartz, agate, jasper, agate, chalcedony, opal, plasma. Today this stone-color raw material is lost forever. At this present time it is an abandoned open pit with a depth of about $30 \mathrm{~m}$ and an area of $10 \mathrm{~km}^{2}$.

Developed complex deposits, where except the main ore component there are semiprecious stone raw materials, are of heightened interest to experts in the stone cutting industry today. However, because of narrowly departmental interests, gem stones are usually stored in dumps or crushed in building gravel, that is they are not mined.

As an example, we will consider several deposits in Ukraine, their role and prospects for the development of science, business, and art.

Iron-ore deposits of Kryvbas are one of the important types of mineral resources of Ukraine. Currently, 21 iron- ore deposits are being developed. The proven reserves of all iron ores of Kryvbas (draw of Kryvyi Rih) are 21.8 billion tons (Metallicheskie i nemetallicheskie poleznyie iskopayemyie Ukraine, 2005). The share of the metallurgical industry of Kryvbas is $60 \%$ of the gross domestic product of the country. 
Unequivocally, the metallurgical industry plays an important role in the modern economy of Ukraine. But we must not forget that over time mined deposits move into the realm of the category of exhausted ones. This leads to an environmental problem, both for the geological environment and for the environment for many decades or even centuries. For this reason, the fate of the Kryvyi Rih region is the present day issue, and it must be solved in current times, until its aesthetic component has not been lost yet.

The aesthetic aspect of iron-ore deposits are raw gemstones. Industrial reserves of decorative jaspilites and low stocks of tiger's eye, chalcedony, quartz, amethyst, calcite dolomite, pyrite, calcite, etc. (Fig.4) are of great scientific and practical interest.

\section{Камнесамоцветное сырье представлено джеспилитом, тигровым и кошачим глазом, халцедоном, аметистом. Запасы их не определены, не добываются и не разрабатываются.}

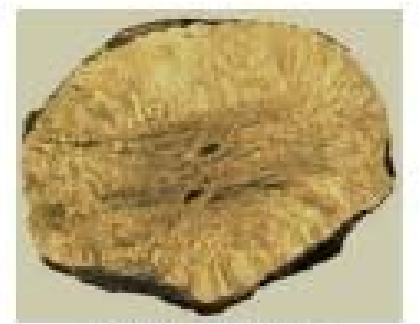

Pyrite Пирит
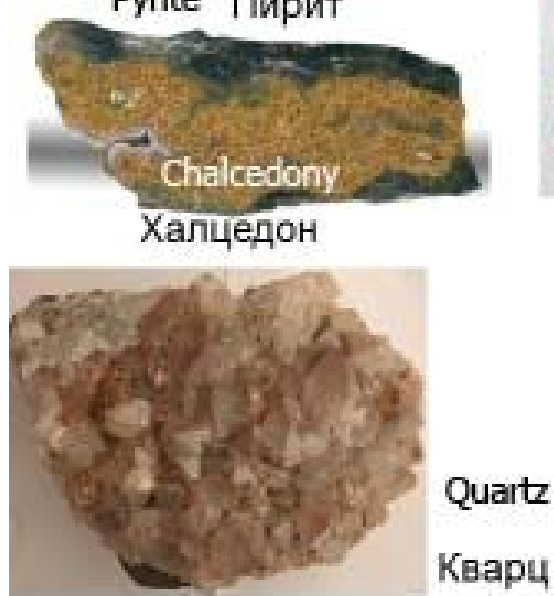

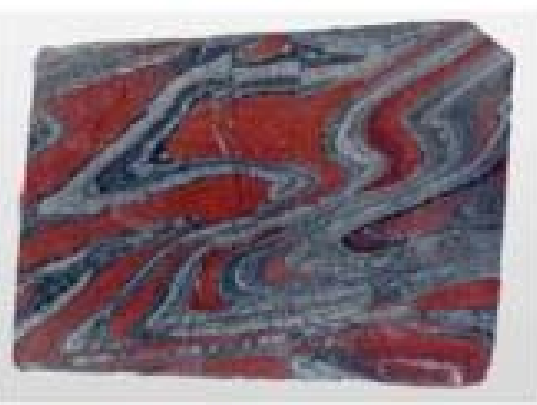

Джеспилит Jasperite

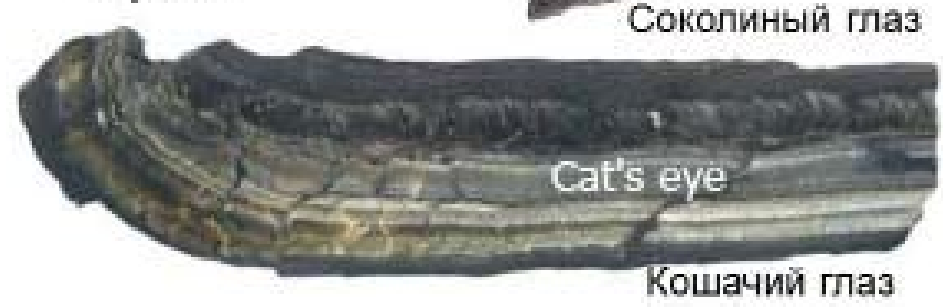

Fig.4. Semiprecious stone material of iron ore deposits from Kryvbas.

One of the dominant idea of stone aesthetics and artistic characteristics of jaspilite is determined by its color and texture.

The colour range of jaspilite includes chromatic (red, yellow, orange and blue) and achromatic colours.

Wide range of colours ensures a variety of textural drawings, which distinguishes favourable jaspilite from other stones. None of the known stones has such a spectrum of texture patterns as jaspilite. They can be conditionally divided into five types: parallel-banded, wavy-striped, puckered, brecciated and landscape.

Characteristic features of the textural pattern of jaspilites are static, dynamics, movement and orientation (direction).

Strict alternation of opaque differently colored layers (bright and dark red, light and dark grey) allows to create a wide variety of decorative and artistic products: bodies of rotation (balls, vases), table cut (three-dimensional geometric bodies, writing sets, jewelry boxes, mosaic), artistic carving (cameos, figures of small shapes) (Fig.5). 

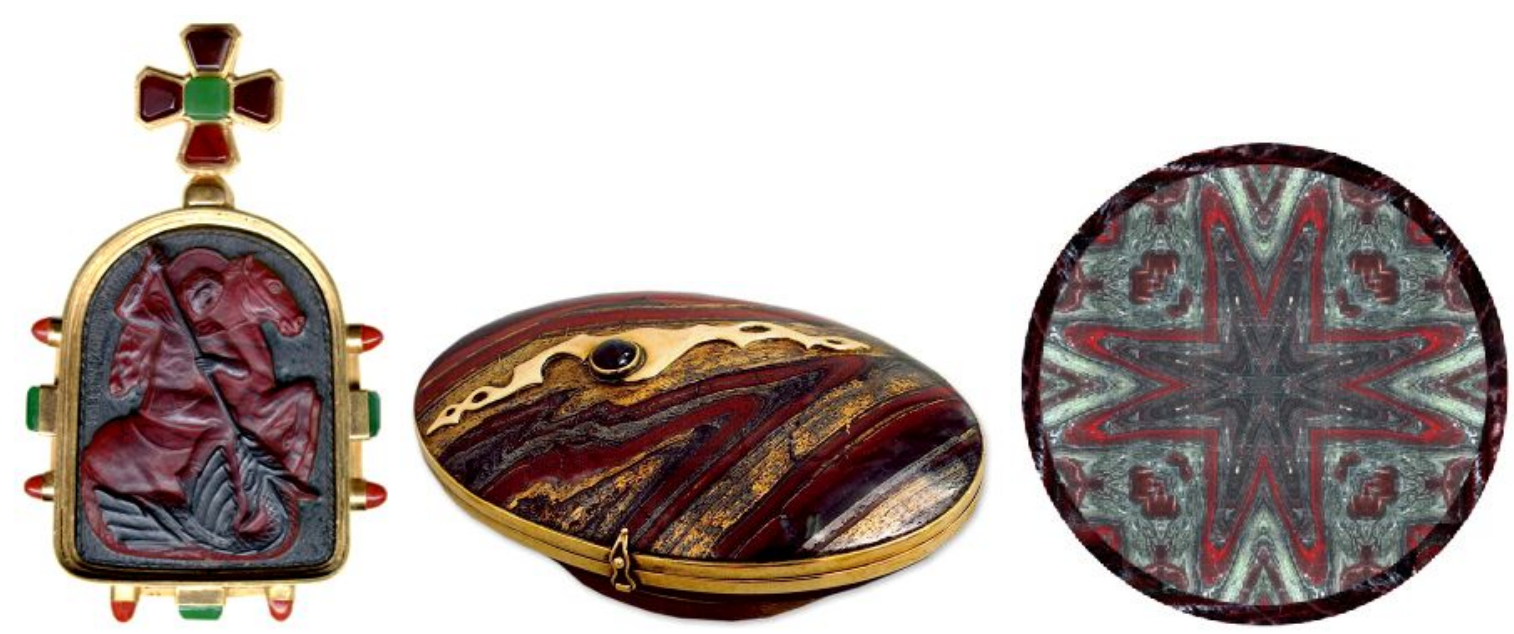

Fig.5. Decorative artistic items of decorative jaspilites (Samotsvety Ukrainy. Dzhespility, 2006).

Recently, there has been a promising direction "Art in stone", where the artistic image of the stone is complemented by oil painting (Fig.6).

The uniqueness and artistry of the stone lies, above all, in its colour range. The theme can be both classical religious subjects and military-patriotic, as well as the events of contemporancity. Fire, sunset

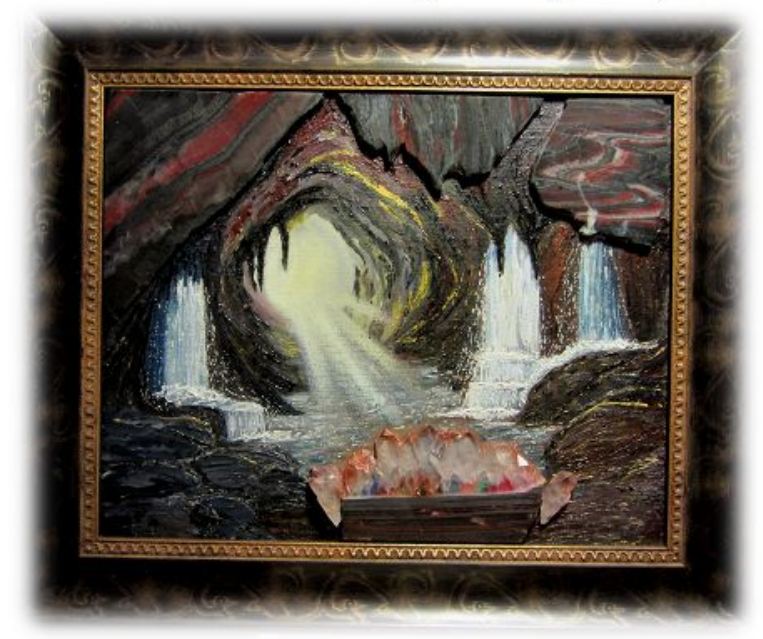

or sunrise, flowers, corals, magma, smoke, etc. these are the associations that the artist sees in this stone. In addition to the mentioned above, the aesthetic properties of the stone get people excited and inspire, cause perturbation and agitation, increase nervous tension, create energy charge, increase the level of anxiety.

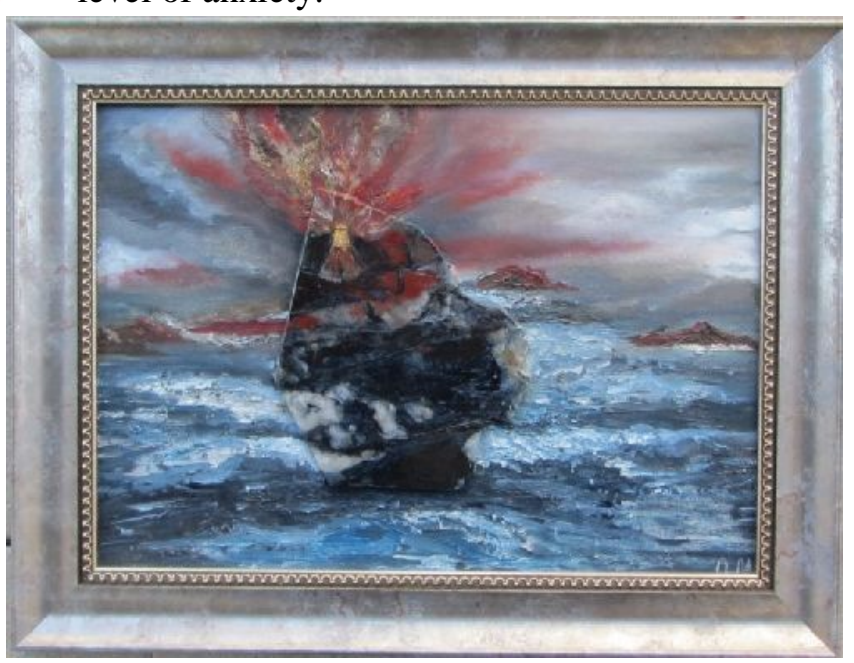

Fig.6. Paintings "Underground Kingdom", "Confact". Artist O. Baranova.

The study of jaspilites together with the production of experimental products revealed three laws of formation in the design of natural gemstones, that is the texture pattern depends on the direction of the plane of cut, the size of the visible surface, and the geometric shape of the stone (Baranov Petr et al., 2009). These laws allow to control not only the texture pattern and colour of jaspilite, but also to influence the feelings and emotions of the viewer.

Today, the old tradition of philosophical and symbolic application and justification of the usefulness of the stone is revived. The concept of the stone as an energy and healing source lies in the intricate patterns, which are determined by the color range of jaspilite. Gaspilite has a very high reputation as a healing stone, it's psychological, astrological and magical characteristics testify to this. The healing properties of the stone are not of mysterious and mystical nature, they lie in the physical and crystal chemical properties of jaspilite, which has a strong magnetic field, due to the high content of magnetite in it. The stone emanates both fire and cold. An original mind sees it as an image of development in art, in which the stone reveals its "soul". An inexperienced reader will be disappointed with the information, having found magical properties of jaspilite on the Internet, because the history of this stone is the history of material substance. The virtual picture of the magic stone is just another illusion. However, 
the magic power of the stone has a rationalistic explanation, which is the presence of polar minerals in composition and properties. This stone, like most gems, is not rare on Earth, it is the real book, which can be used to study the history of the formation of the earth's bowels of some parts of the earth. This is a kind of chronicle, imprinted in stone; a book, which contains the greatest enigma of the Nature, and which keeps its deepest secrets - the mysteries of the emergence of the immaculate in its fiery cold beauty of the stone. This stone has a huge potential, which is unexplored until the end. But the first decisive steps in the design development and practical testing of jaspilite or picture jasper have already been made. This is the stunning with its audacity even the most exquisite and sophisticated imagination, the project of the Jaspilite room, which can become a Museum relic of Ukraine, like malachite or Amber rooms Jaspilite room (Fig. 7).

The monograph "Gems of Ukraine" is devoted to the stone, which played a breakthrough role for the Dnieper region. Five projects of Jaspilites rooms in classical, Gothic and also modernist styles are presented here (Samotsvety Ukrainy. Jaspilite, 2006). The task of modern jaspilite artists to implement design tactics of a jaspilite master in stylized gothic, ancient myth or legend, gothic, classic or modern architecture and interior.

The goals and tasks of modern masters of stone - to integrate the stone into the design landscape of the Dnieper region, the Ukrainian interior, to make this stone a worthy representative of the Ukrainian state, a symbol of its wealth and glory. It will not be long - a concrete practical implementation of the project, which is possible with the involvement of interested people who can help in the implementation of the project. To do this, the material and spiritual efforts of those who sincerely love Ukraine and longs for its prosperity should be united. The most interesting thing is that this project is not something abstract or unreal. It can become one of the most fruitful and promising design and art national projects of Ukraine. It is difficult to accept the extraordinary and unconventional idea of the prospects for the development of the Jaspilite room as a decorative, applied and artistic work. Knowing of the artistic value of the stone should inevitably lead to practical work, the transition from the project, artistic fantasies and theoretical work to the implementation of practical tasks that are set before the design team.
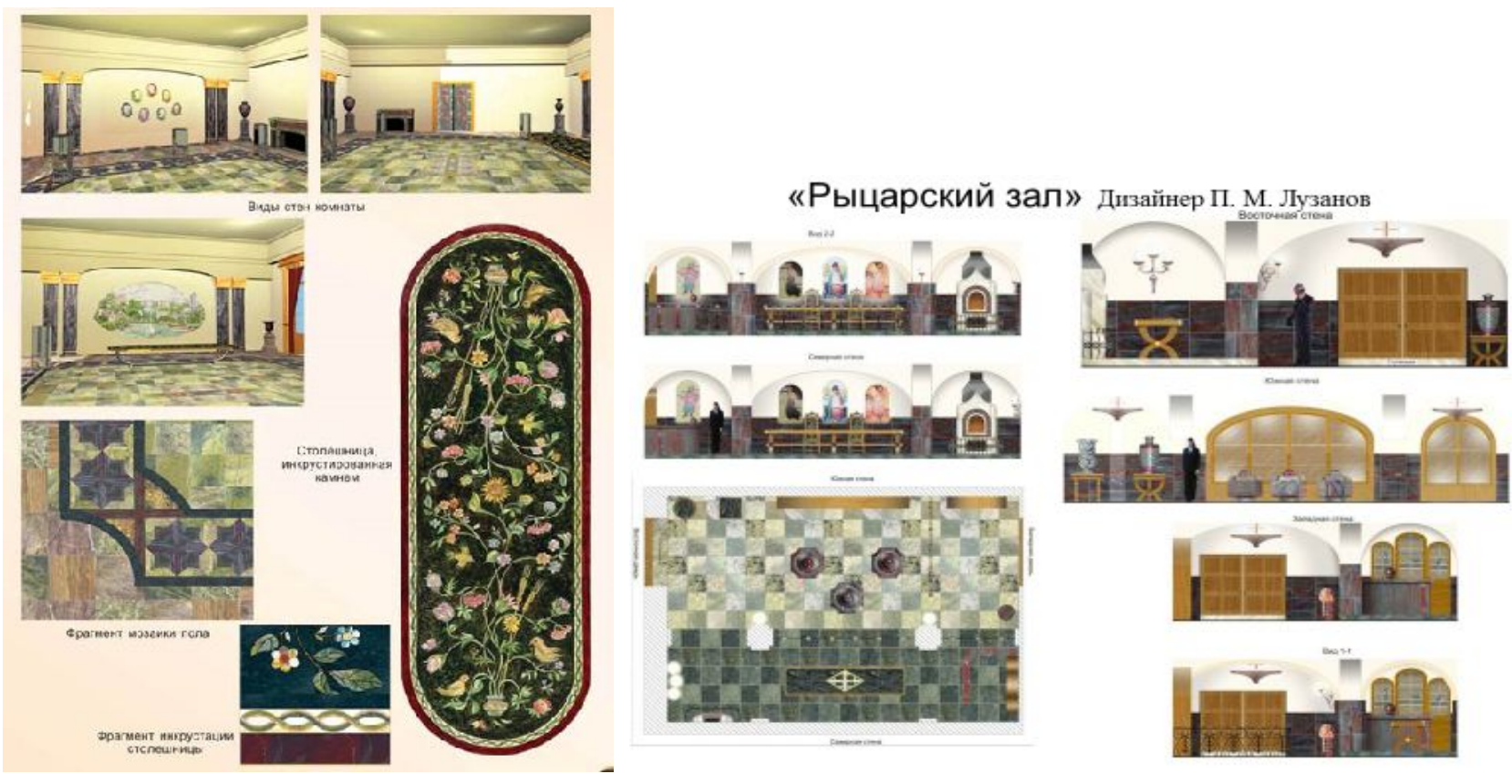

Fig 7. Sketch designs of Jaspilites room: Cantata about the stone (author I. N. Buryak), Knight hall (author M. P. Luzanov) (Samotsvety Ukrainy. Jaspilite, 2006).

Thus, the developed iron ore deposits have the opportunity to become not only an industrial, but also a cultural and educational centre.

And although at the present time, with the help of minerals material goods are created, the task of the present days concerning using of geological objects is the formation sports and recreation and cultural centers (museums, bases, unique works of art) on their basis, the development of popular scientific tourist routes, etc. The implementation of this idea will be the basis for the development of the stone-colored market, national traditions and the culture of stone in the region. But, alas, despite these 
prospects, the society is not ready to create a future for our children yet.

Deposits of written pegmatites. The Eliseyevskoye pegmatite field is still interesting for commercial structures, as it includes 15 lodes, one of which is currently being developed for ceramic raw materials - the field "Balka Bolshogo lagerya", where the written pegmatite is about $40 \%$. The stone is a rich in texture patterns and sizes of textureforming elements (ichtyogliptes). According to the drawing and the colour scheme, eight varieties of written pegmatites (Fig. 8) are distinguished on the deposit: gently pink, soft brown, spot violet, parquet pink, gigantic purple, leopard, snow white and violet-pink (Slivna O.V., Baranov P.M., 2015).

As lodes contain decorative raw materials (written pegmatites), which many times exceeds the cost of ceramic raw materials, at the present time the deposits of written pegmatites need a revaluation, taking into account the stone-colored raw materials. Pegmatite refers to semi-precious stones of the second order. It is a relevant and interesting material for jewelry and stone processing industries. Traditionally, written pegmatite is used as an ornamental stone for stands, boxes, countertops, decorative pebbles. However, at the present time, the results of the
Italian company "Antolini", which use graphic pegmatite in interior design under the trademark "Zebradorite", are interesting. At the same time, Ukrainian written pegmatite is not present on the market and is not valued as a stone-colored raw material.

In general, the Srednepridneprovsky megablock of the Ukrainian Shield, as studies have shown, has great prospects for stone-colored raw materials. It includes granite deposits, where epidosites, mylonites, tectonites, gangue quartz of different color paint are used as gems. At this moment, they are used as building materials (quarrystone, crushed stone, crumbs, etc.), although, according to the Ukrainian legislation, epidosites and colored quartz are semi-precious stones of the second order. The most interesting from an aesthetic standpoint are decorative tectonites, first installed during the tunneling of the Dnepropetrovsk underground. Subsequently, such formations were discovered on the Tretuznenskiy granite quarry (near the town of Kamenskoye), which can serve as a prototype object in the identification of promising areas of stone-colored raw materials in the Srednepridneprovsky megablock of the Ukrainian Shield. Here, for the first time, blue-black quartz was discovered at the contact of granitoids and ultrabasic rocks.
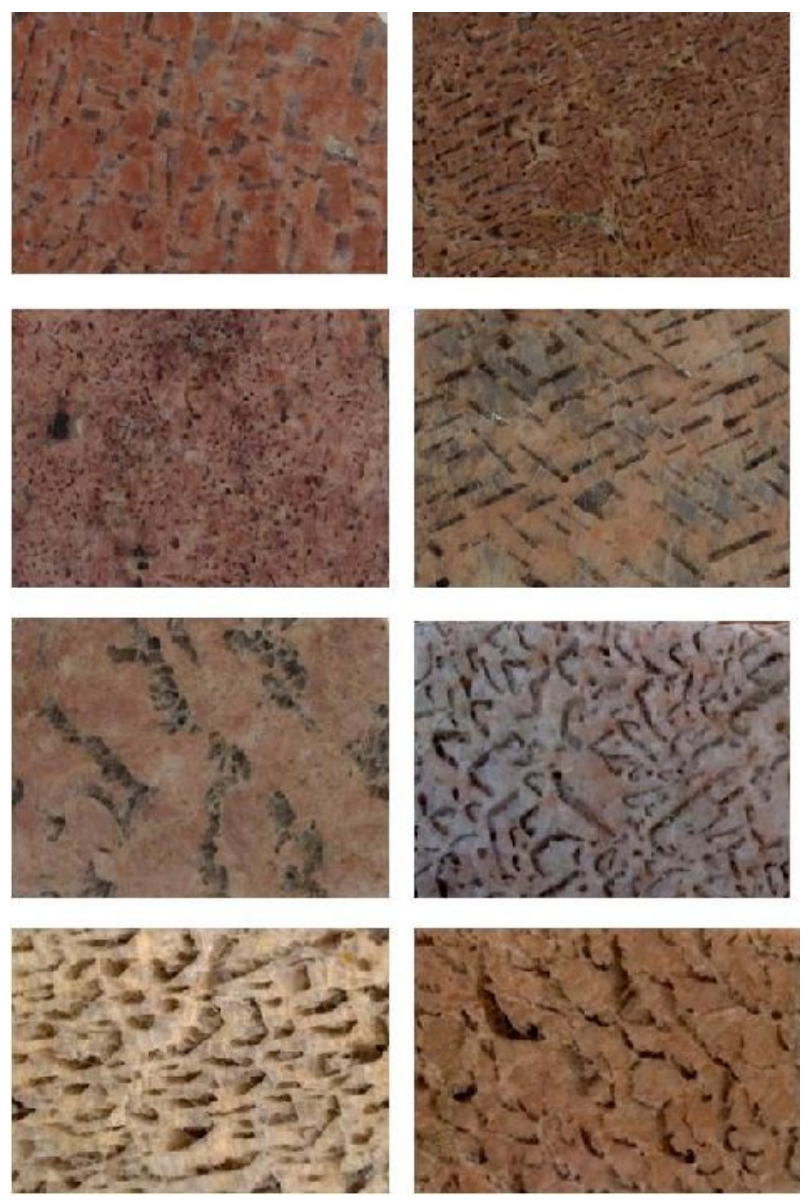

Fig. 8. Decorative varieties of pegmatites of the deposits "Balka Bolshogo Lagerya» (Slivna O.V., Baranov P.M., 2015). 
The malachite deposits of the Democratic Republic of the Congo (Zaire) are an example of squandering of national wealth.

Malachite deposits were discovered at the beginning of the 20th century. In size and reserves (over 1000 tons), they are unique, and the country occupies a leading position in the world market for the extraction of malachite (approximately 10,000 tons of ore produce about 100 kilograms of jewelry malachite).

The quality of malachite and its application in arts and crafts were determined on the basis of studying the decorative and technological properties of the stone (Baranov, P.N. et al., 2006).

In the course of experimental works, decorative and artistic and jewelry items of the most different level were made (Fig. 9).This allowed to establish that the criteria for assessing the quality of malachite are the mass and shape of the samples, polishing, color, and pattern. In some cases, the criteria for assessing of the quality of malachite may be the inclusion of foreign minerals (pseudomalachite, azurite, broshantite) and host rocks, as sometimes they give special originality to malachite (landscape paintings).

High-quality Zaire malachite is illegally exported from the country, and high-quality products made of it are often given out for the Ural one, which has worldwide fame on the world market. At the same time, local residents (the Congolese) make low-quality products from malachite. Thus, bright gem is completely dissolves in society, leaving no trace in art, culture and history. Huge useless quarries remain on the site of waste deposits.

Explored deposits. Currently, deposits that contain collection and semi-precious stones are on balance of the Geological survey of Ukraine (GKZ). One of them is the Shevchenkovskoye Deposit of spodumene pegmatites, located in the South-Eastern part of Ukrainian shield. In addition to the lithium mineralization there are wide fields of lithium pegmatites of nitro type here: microcline graphic, albite, spodumene pegmatites. There are interesting samples of pink spodumene (kunzite), petalite from light green to pink, tourmaline (sherl) (Baranov p. N., Kichurchak V. M., 1992). But the secrecy of this object did not allow carrying out Gemological assessment during geological exploration, so the true cost and the future fate of this field was not determined.

Thus, explored deposits require a comprehensive assessment of minerals regardless of ownership and secrecy, because this is our planet and this is our task. As V.I. Vernadsky wrote, the highest stage of the biosphere development is a reasonable transformation of the primary nature of the Earth in order to make it able to satisfy all material, aesthetic and spiritual needs of the numerically increasing population (Vernadskiy V. I., 2002). This requires a spiritual conviction of society that the geological environment and its minerals are not a pantry, where you can only take from. We must understand that this is not a momentary benefit, but the future of our society and our planet Earth

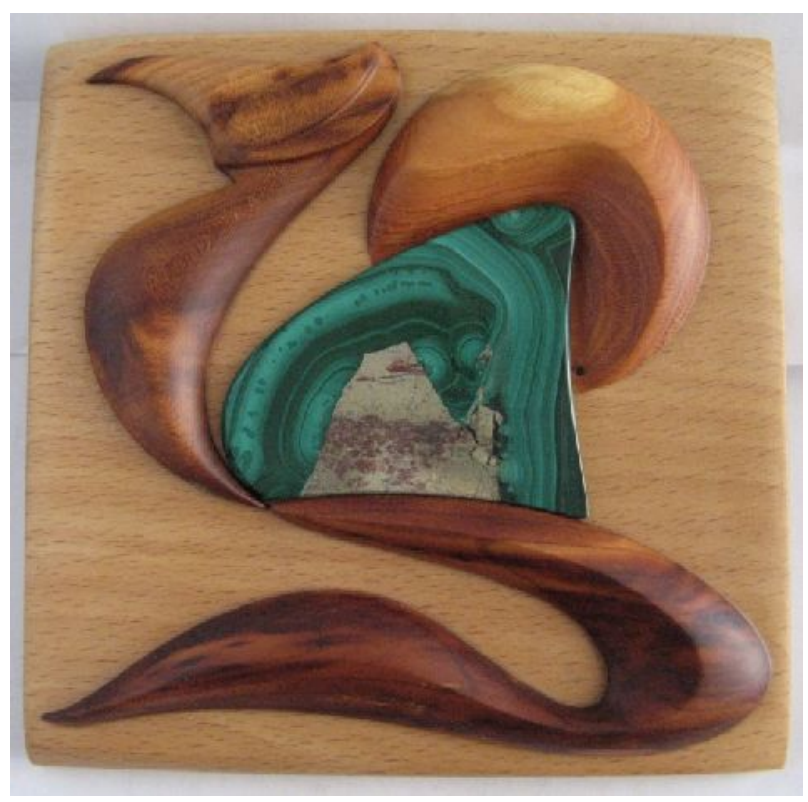

Fig. 9. Works from malachite DR Congo. The watch on the sketches of Faberge. Panel picture "Landscapes of Africa." 
For a full understanding of the essence of ecological aesthetics, and knowledge of the beautiful in nature and further savings, you need to realize that the aesthetics of the nature requires the development sensibility, contributing to the pleasure of stay in a natural environment, in a man. Ecological aesthetics in this sense is a philosophy of harmony between man and nature, the emergence of which becomes possible only in a certain cultural context of modernity.

Conclusions.1.The exhausted deposits are divided into three groups according to the degree of eco-esthetics: deposits that have become cultural and educational centers; deposits that played a large role in culture and art; deposits that have lost stone-colored raw materials. The aesthetic aspect plays a major role in their future. In the presence of aesthetic, historical and other interesting factors, these deposits become attractive for investment in the development of popular science tourism. The society becomes spiritually richer, and the environment is safer and more beautiful if the exhausted deposits turn into cultural and educational centres.

2. Developing and explored deposits of raw gemstones are in urgent need of re-evaluation and development of the ecological and aesthetic projects with economic, environmental, and aesthetic positive indicators.

3. The obtained data suggest the development of highly effective aesthetic projects to restore the disturbed geoecological environment. To understand the ecological situation in the region, first of all, it is necessary to make an ecological and aesthetic inventory of deposits with stone-and-stone raw materials.

\section{References}

Baranov, P.N., Kichurchak, V.M. 1992. Tipomorfizm vklyucheniy $\mathrm{v}$ kvartse spodumenovyh pegmatitov
Ukrainy.[Typomorphism inclusions from quartz of spodumene pegmatites of Ukraine]. Mineralogicheskiy zhurnal, 14, $84-87$ (in Russian).

Baranov P.N., Kutsevol M.L. 1998. Kamnesamotsvetnoye syrye gruppy kremnezema na mestorozhdenii nikelya v Srednem Pobuzhye.[Semiprecious stone material of the group silica in the Deposit of Nickel on Average Pobuzhzha]. Sbornik nauchnyx trudov NGA Ukrainy, Dnepropetrovsk: RIK NGA Ukrainy, 188-189 (in Russian).

Baranov, P.N., Mukendi E., Shevchenko S.V., Bogdanov V.M., Baranov A.P. 2006. Mineralogo-gemmologicheskaya harakteristika malahita Katangskogo mednogo poyasa (DR Kongo). [Mineralogical and Gemological characteristics of malachite Katanga copper belt (DR Congo)]. Koshtovne ta dekorativne kaminnya, 1(43), 19-25 (in Ukrainian).

Baranov Petr, Shevchenko Sergey, Heflik Westlaw, Dumanska-Slowik Magdalena, Natkaniec-Nowak Lucyna. 2009. Jaspillite - a gemstone from Ukraine .The Journal of Gemology.Vol. 17, 3, 2330 (in English)

Fersman, A. E., 1961. Ocherki po istorii kamnya. [Essays on history of stone]. Vol. 2. Moscow: AN SSSR (in Russian).

Metallicheskiye i nemetallicheskiye poleznyie iskopayemyie Ukrainy. 2005. [Metal and non-metallic minerals of Ukraine].Vol 1, Kiev - Lvov: Izd-vo «Tsentr Evropy» (in Russian).

Samotsvety Ukrainy. Dzhespility. 2006. [Gemstone from Ukraine. Jaspillite]. Vol 2. Kyiv: YuvelirPRESS (in Russian).

Slivna, O.V., Baranov, P.M. 2015. Geologo-promislovi kriteriyi otsinky yakosti pismovyh pegmatytiv Elisiyivskogo rudnogo polya [Geological and industrial criteria of quality evaluation of written pegmatites from ore field Yelisiyivske ]. Koshtovne ta dekorativne kaminnya, 1, 8-12 (in Ukrainian)

Vernadskiy, V.I. 2002. Biosfera i noosfera [The biosphere and the noosphere]. M.: Rolf, (in Russian). 